\title{
Unintended Consequences: the U.S. Postal Service Conundrum of Service, Business, Labor, and Politics
}

\author{
Philip F. Rubio ${ }^{1}$
}

Accepted: 2 March 2021 / Published online: 30 March 2021

(C) The Author(s), under exclusive licence to Springer Science+Business Media, LLC, part of Springer Nature 2021

\begin{abstract}
This paper examines the 2020 turmoil surrounding the U.S. Postal Service-a crisis not seen since roughly 209,000 employees struck its predecessor the U.S. Post Office Department in March 1970, which led to passage of the Postal Reorganization Act that summer and the inauguration of the USPS in July 1971. The 2020 conflict was not merely rooted in the economic disaster following the COVID-19 pandemic, but in fact stretches back to the 2009 postal financial crisis. I argue that these crises are an unintended consequence of the compromise formation of the USPS as a hybrid government agency/business. Debates over whether public or private postal service too often leave out conflict over the rights of postal labor. The origins of that debate lie in the former USPOD's management of labor using "business methods" that included authoritarian discipline, contingent workers to cut costs, and creating racial divisions among employees.
\end{abstract}

Keywords U.S. Postal Service · Business · Richard Nixon · Wildcat strike · Unions · Universal service

\section{COVID-19 2020: the USPS Conundrum Explodes}

On April 9, 2020, the U.S. Postal Service (USPS) warned that it could run out of cash to run daily operations by September 2020 because of a huge loss of revenue as mail volume plummeted-especially from businesses-due to the COVID-19 pandemic. That was the announcement by Megan Brennan, a former letter carrier who was the seventyfourth postmaster general, the thirteenth of the USPS, the first woman appointed to that position, and the fourth in a row to be a USPS career employee (Bogage, 2020g; Johnson, 2020; Rushing, 2020). Brennan's retirement officially came on June 15, 2020, with the appointment by the USPS Board of Governors (BOG) of Louis DeJoy, a major donor to President Donald Trump and the Republican Party, and whose postal experience is quite different: twenty-five years of USPS contracts for logistics support (Heckman, 2020; Piette, 2020). We can reasonably assume that Trump has seen DeJoy as an

Philip F. Rubio

pfrubio@ncat.edu

1 Department of History and Political Science, North Carolina Agricultural and Technical State University, Greensboro, NC 27411, USA 
ally in the USPS. This is especially the case with DeJoy's cost-cutting measures that have also curtailed mail service across the country, shaking confidence in the USPS and its ability to handle mail-in ballots in November-balloting that Trump has dismissed (without evidence) as fraudulent (Rein \& Bogage, 2020; "Return to Sender", 2020; "USPS Reaches Agreement”, 2020).

It is always risky to try and write history as events unfold. Nevertheless, tackling the ongoing debate over postal privatization without mentioning current events misses an opportunity to highlight in real time the contingency of historical action. All the pieces are in place to tell this story regardless of what political drama occurs next-and much more is expected after this writing. Indeed, the post office has never seen this much political conflict in its 245-year history-to the point where many wonder and worry over its future (Rein \& Bogage, 2020). As well, there has never been this much turmoil surrounding the USPS since approximately 209,000 employees struck its predecessor the U.S. Post Office Department (USPOD) in March 1970, which led to passage of the Postal Reorganization Act that summer and the inauguration of the USPS in July 1971 (Rubio, 2020d; United States Postal Service, 2020b). The current conflict is not limited to the COVID-19 pandemic, but in fact stretches back to the 2009 postal financial crisis that seems unending. I argue that this is an unintended consequence of the compromise formation of the USPS itself as a hybrid government agency/business. In addition to debates over whether this service should be public or private, we too often leave out the other half of USPS debates over the rights of postal labor. The origins of that debate lie in the former USPOD's management of labor, making use of "business methods" that included authoritarian discipline, hiring contingent workers to cut costs, and encouraging divisions among employees over race (President's Commission on Postal Organization, 1968; Rubio, 2010).

It is easy to miss the labor component to this ongoing crisis owing to the preponderance of criticism aimed at the USPS service model by Trump and Senate Republicans. Trump dismissed Postmaster General Brennan's 2020 request for bailout funds to help with the $\$ 13$ billion in revenue losses due to the pandemic, along with projected losses of $\$ 22$ billion over the next 18 months. In April, Trump even vowed to block a $\$ 10$ billion loan earmarked for the USPS under the CARES Act unless the USPS increased parcel rates, and Treasury Secretary Steven Mnuchin asked for the power to demand labor concessions and oversee senior executive appointments (Rein \& Bogage, 2020). The loan finally was approved July 29 without labor contract changes or parcel rate increases, and the appointment of Postmaster General DeJoy rendered the appointment condition moot. However, the loan agreement did obligate the USPS to provide proprietary information about their largest private-sector contracts to the Treasury Department (Bogage, 2020e).

Trump's reported personal animus toward Amazon CEO and Washington Post owner Jeff Bezos should not distract us from the collective forces that support USPS privatization, led by Trump's own failed June 21, 2018 proposal to Congress that included the termination of collective bargaining for postal unions (Rubio, 2020d). Those include the American Postal Workers Union, the National Postal Mail Handlers Union, the National Rural Letter Carriers Union, and the National Association of Letter Carriers (NALC). One wonders what happened to the intended "divorce" of politics from the daily operations of what would become the USPS, as another Republican president, Richard Nixon, called for in 1969 when he proclaimed, "There is no Democratic or Republican way of delivering the mail. There is only the right way" (Nixon, 1969). 


\section{The 1970 Postal Strike, the USPOD, and the USPS}

In refuting Trump's diatribes against the USPS and its alleged bad business practices, historian Richard John correctly characterized the founders' intent that the post office should be a service, not a business. That fundamental service model has remained up to the present time, including the transformative 1970 Postal Reorganization Act (PRA, also known as Title 39 of the U.S. Code), and the 2006 Postal Accountability and Enhancement Act that amended it (John, 2020). However, even before the USPS, the USPOD also operated "like a business" in the sense of its management of labor and selling postage. Postage and taxpayer funds approved by Congress paid the USPOD bills and employees. However, that did not stop the USPOD from trying to increase worker productivity and cut labor costs. Ironically, labor rights that expanded considerably in 1971 with the operations of the new USPS have also paid the same price of vulnerability to political whims that the USPS itself faces today. Absent the automatic congressional financial support that existed for the USPOD, we have now witnessed the possibility of the USPS becoming insolvent and forced to shed jobs as well as services if future congressional support is not forthcoming (Bogage, 2020g; Rubio, 2020c).

The fact that the post office has always been a service, yet for years also functioned as a business even before it became the USPS, goes to the heart of its conundrum today, including the promise (or threat) of privatization by Trump. That conundrum is baked into the USPS's very design and can only be managed successfully in a similar atmosphere to the one in which it was founded, namely that of bipartisan political agreement (Rubio, 2020d).

Ten months before the March 18, 1970, nationwide illegal postal wildcat strike that began in New York City for decent, comparable wages and job dignity, Nixon had given Congress an inspired speech on May 27, 1969, which concluded with the words quoted earlier. In that speech, he lamented how the post office had fallen behind the times and failed taxpayers along with the "three quarters of a million dedicated men and women who today wear the uniform of the postal service" (Nixon, 1969). By way of remedy, Nixon proposed a "modernized" new hybrid government agency/corporation he called the "United States Postal Service." Nixon evoked masculinist construction worker imagery to make the case that this was the best way to put "tools" in the hands of postal workers to do their jobs effectively. He peppered his speech with remarks that seem ironic today yet are also indicative of the fundamental service/business dilemma. Nowhere in the 1970 PRA is there mention of "business," "business model," or "corporation." For that matter, any associated language like "customers," "breaking even," or even "self-supporting" is noticeably missing. Yet Nixon used some of those very terms in his May 1969 address to Congress that represented a revision of the USPOD original draft speech that their general counsel David A. Nelson had sent to the White House a couple of weeks earlier. It is possible that in that revised draft is where we first encounter the idea explicitly advanced that the future USPS should "operate like a business"-although Nixon did aver that Congress should still provide funds on occasion for public service groups (Nelson, 1969).

Nixon's entire speech bears reading. In it we see him attempt to "sell" his proposed commercialized postal government agency to Congress based on two paradoxical tropes: 1) the "inefficient non-businesslike" government agency that had routinely run up deficits since 1838; and 2) the underpaid, disempowered postal workers who deserved better, as did their bosses and customers. For Nixon, mail processing and delivery would be better performed in the future with "business methods." While making these grand promises, Nixon meanwhile kept wage raises low for postal workers, rejected their full collective 
bargaining rights within a reformed USPOD, and tried to hold postal raises hostage in early 1970 unless his postal corporation bill was passed (Rubio, 2010, 2020d).

Richard John has also noted that historically, Congress typically gave the USPOD whatever it asked for by way of annual appropriations. These were annual subsidies, not bailouts (John, 2020). What then, did Nixon mean when he said that the post office should "operate like a business?" Does self-funding make organizations inherently more efficient as opposed to those that rely on taxpayer money while simultaneously earning revenue by selling their products? That would include the USPOD, which was also mandated to provide universal service at reasonable rates. Until 1971, Congress also had the power of the purse over postal wages and benefits and was notorious for keeping both low. Some context is worth remembering here that includes the Progressive-era scientific management campaigns to cut postal wages and increase productivity with new time-management methods (Mikusko \& Miller, 2014; Rubio, 2010, ch.1, 2020d, ch.1).

The USPOD also found other means to save labor costs such as requiring "Part-Time Flexible" employees to wait until enough mail had accumulated before "clocking in" to work (Mikusko \& Miller, 2014; Rubio, 2020d, ch.1). The USPS inherited and reproduced these methods with constant campaigns to cut labor costs. These included the notorious attempted "Kokomo Plan" of timing letter carrier work in the 1970s. For distribution clerks, there was constant management pressure to process mail quickly both manually and by machine according to management standards. And post offices frequently have been sites of daily shop floor clashes between supervisors and carriers over getting the maximum amount of mail out without using overtime or getting "auxiliary assistance." Supervisors, who are often former carriers themselves, to this day are quick to remind letter carriers that they are leaning on their former co-workers because they have to "get their numbers up," which is to say, leaving as little non-preferential mail behind as possible ("non-preferential" refers to mail that is not first class, priority, newspapers, or time-sensitive business mail).

The USPOD from 1775 to 1971 was the predecessor to the USPS. It began as America's political and information network. It promoted newspapers, letter-writing, national development, innovation, and invention (Acemoglu et al., 2016; United States Postal Service, 2020b). There is not enough room for a full discussion here, but the post office has not historically been a singularly progressive force, nor even a neutral institution. For example, during the first half of the nineteenth century it became the contentious center of political debates over the free circulation of abolitionist and other literature, as well as over patronage and power. It lost the telegraph to private industry then also. But it won the right from Congress to establish postal banking and parcel post in the early twentieth century because of private industry neglect and gouging of customers. Moreover, it has both enabled and suppressed black and female labor throughout its history (Rubio, 2010, 2020d).

The USPS as the successor to the USPOD was a product of contentious 1960s political debates over USPOD growing deficits, technological lags, repressive work culture, and finally a 1970 postal wildcat strike that forced the issue over wages, worker rights, and the future status of the post office. Sociologists Thomas Germano and Vern Baxter have both written on the problems with how service culture began to look more like business culture in the transition from the USPOD to the USPS - even as problematic and authoritarian as that USPOD overall work culture had once been (Baxter, 1994; Germano, 1983).

The post office in 1970 was a story of partisan wrangling and ultimately bipartisan compromise prodded by a massive labor action. There were political choices that postal unions preferred, such as collective bargaining rights within a reformed USPOD along with a living wage. However, the hybrid that was constructed ultimately made the USPS vulnerable to devastating congressional oversight in the PAEA in 2006 that hobbles it today. 
Separating politics from the nation's mail was always an illusion. The PRA that poetically called for the USPS to "bind the nation together" never intended to make the USPS profit driven as a later partisan ideology came to frame it. Quite unintentionally, however, its founders set the stage for the popular de facto reframing of the post office as a "business" in speeches and position papers leading up to and immediately following the PRA's enactment (Rubio, 2020d, chs.2-6). The political and financial vulnerability of the USPS was never inevitable but was in fact contingent on privatization forces who were able to directly access political power in both the executive branch and the USPS itself. These forces, as journalist Lisa Graves recently pointed out, revolved in part around "free market" conservatives associated with billionaire Charles Koch and think tanks like the Cato Institute and Citizens for a Sound Economy (later Americans for Prosperity). Unrequited postal privatization efforts during the 1980s administration of President Ronald Reagan finally found fruit during the George W. Bush administration of the early 2000s. Certainly helpful for those forces was the appointment of Koch protégé James C. Miller III to the USPS Board of Governors (BOG) in 2003, and later elected BOG chair in 2005. Miller was instrumental in the passing of the PAEA (Graves, 2020; Rubio, 2020d, ch.8). Besides limiting its ability to sell certain products and services, the PAEA imposed massive annually accruing debt on the USPS. That debt provided the appearance that the USPS was a poorly run businessa narrative privatizers promoted during the 2020 pandemic (Graves, 2020; Kosar, 2009; Rubio, 2020c, 2020d, ch.8; Sherman, 2020).

\section{DeJoy's 2020 Mail Slowdown and the Prior Postal Crisis}

In early July 2020, after massive volume and revenue losses due to that pandemic, leaked USPS internal documents signaled Postmaster General DeJoy's willingness to treat the service as a business, curtailing mail and rationalizing labor ostensibly to avoid insolvency. In early August, DeJoy conceded that those had been his policies. Major media outlets by then had already pointed out that this could have especially disastrous effects for mail-in voting in November, with the pandemic by now showing no letup (Bogage, 2020b, 2020f; Lee \& Bogage, 2020; Slisco, 2020; Waldman, 2020). DeJoy's subsequent July 28 statement on "operational excellence and financial stability" seemed tone-deaf to the harm his policies were causing to service as he blamed a "broken business model" for the USPS crisis without even mentioning the pandemic or the PAEA continuing debt crisis (DeJoy, 2020).

The USPS has never been a business, earns no profits, has no shareholders, and has received no taxpayer funds since 1982. In addition to its universal service obligation, there are legislated product constraints in the PAEA designed to protect private carrier competition (Graves, 2020; Rubio, 2020d, ch.8). There is real irony in the "broken business model" trope invoked by DeJoy and others. In fact, the disastrous results of cutting transportation and overtime costs (with an expected annual savings of only $\$ 200$ million), as well as dismantling mail-sorting machines, mothballing collection boxes, and cutting retail hours, damaged what the USPS is best known for-its dependable service (Hutkins, 2020c; Ingraham \& Guskin, 2020; Viebeck \& Bogage, 2020).

Self-defeating business decisions like these could typically cost CEOs their positions in the private sector-unless they were managing a private equity firm whose mandate was to restructure a failing business to benefit the firm's shareholders. DeJoy as postmaster general, ironically has been able to make these kinds of decisions based on the semi-autonomous public-sector status of the USPS, without accountability to anyone but the PRC, the 
USPS BOG, and Congress. Asserting oversight powers over the USPS, Democrats in early August asked the USPS OIG (Office of Inspector General) to investigate DeJoy's policies and practices (Bogage, 2020c). Democrats in Congress also called DeJoy to appear for an August 24, 2020 hearing before the House Oversight and Reform Committee on the impact of USPS slowdowns on mail-in balloting. In the week before that hearing, intense heat from consumers, postal unions, the media, and politicians elicited promises from DeJoy to suspend those policies until after the election, as well as dropping its carrier "test" plan to settle the NALC's national grievance (Bogage, 2020a; Broadwater et al., 2020; Edmondson et al., 2020; National Association of Letter Carriers, 2020b).

That test plan began with a July 16 USPS letter to the NALC that, according to the union contravened the postal policy manual and the union contract in conducting a "test" for the next 30-60 days in 384 delivery units around the country starting July 25. It required carriers in those units to take their presorted mail directly to the street in the morning and not wait for any other late arriving first-class mail until they returned to the office in the afternoon (National Association of Letter Carriers, 2020d). The NALC filed a national-level grievance in August (National Association of Letter Carriers, 2020a), along with an NALC press release informing the public that letter carriers were "angry, frustrated and embarrassed" at the new service cutbacks (National Association of Letter Carriers, 2020c). The NALC did not indicate the USPS's rationale, but some possibilities include providing 1) cover for DeJoy's national mail delay policies; 2) data for future collective bargaining negotiations, and 3) justification for making permanent these radical mail sortation changes. Whatever the case, postal workers in all crafts and units found themselves forced to violate their training to leave no mail behind and always work for "the good of the service" (National Association of Letter Carriers, 2020e; Rubio, 2020a).

Strangely, a USPS memo from DeJoy and Executive Vice President Isaac Cronkhite from August 7, 2020, on organizational restructuring, concludes with a commitment to "involve employees in the process and communicate." These words are belied by the unilateral service initiatives cited above, not to mention the reassignment of 23 senior executives and a senior-management hiring freeze widely referred to as the "Friday Night Massacre" (DeJoy \& Cronkhite, 2020; Politi, 2020). These policies as noted above, negatively affect both service and labor rights. DeJoy's repeated emphasis on "efficiency" found a new twist in his remarks to the BOG meeting on August 7, where he noted that the USPS had been marked by "ingrained inefficiency" (United States Postal Service, 2020a). However, as Vern Baxter once pointed out, "Efficiency is a prevailing institutional myth of the modern post office, and it has usually been operationally defined as scientific management of labor to secure greater standardization and intensity of effort a reduced cost to the government" (Baxter, 1994, 56).

It must be remembered that the USPS is a not a hapless public service victim of outside privatization forces. Under the helm of President Bush's postmaster general appointee, John Potter, the USPS in 2002 displayed sympathy for partial privatization and rollback of labor rights in a discussion of three possible models. Those included: 1) return to government agency format, 2) privatization, and 3) (its preference), a "commercialized Postal Service" which the USPS concluded "would need to operate more like a business" (United States Postal Service, 2002, 65-75, quote on 65; Graves, 2020). The USPS's 2002 Transformation Plan was followed in 2003 by a Bush administration task force that shared those sentiments on making service and labor adjustments while framing the low employee "quit rate" of less than 1.5 percent as problematic (President's Commission on the United States Postal Service, 2003). The low-waged but dependable postal job with a 26 percent turnover in 1969 had now become a desirable career. Nixon hated unions but accepted them as the 
price to be paid for high productivity and labor peace, especially after the 1970 strike. For Nixon and others who supported his postal corporation idea (including Postmaster General Winton Blount), unions were a normative part of modern corporate life. Nixon recognized postal workers' drive for wage "comparability" (not with auto or steel but rather shipping clerks and delivery drivers), good wages and benefits, and strong unions to enforce labor peace. This was a vision he shared with AFL-CIO President George Meany, who prior to the strike did not really exhibit much interest in government workers (Cowie, 2010; Halpern, 2003, ch.5). "Comparability" in fact is written into the PRA (Postal Reorganization Act, 1970, 101 (c)). In some ways, postal work would become a more secure job than the auto and steel industries that faced layoffs and "runaway shops" starting in the 1970s. Even without the right to strike, postal workers enjoyed not only mediation and arbitration of contract negotiation breakdowns with the PRA, but also a "no-layoff" clause after six years of service as of 1978 (Rubio, 2020d, chs.5-6).

The year 1981 was the last time postal unions threatened to call a formal (and still illegal) strike. Postal workers were relatively well-paid with good benefits, but they also enjoyed less sympathy when they threatened to strike than when they struck in 1970. In 1970, they had shocked America by striking the government, but they also revealed how shockingly low their wages were. Fortunately, postal unions in 1981 did not suffer the fate of the Professional Air Traffic Controllers Organization (PATCO)-crushed by President Reagan after its strike that year. Mediation and arbitration produced decent USPS contracts when talks broke down. The hostility to the USPS as a public service by conservatives now merged with their opposition to strong postal unions that had won some successes in collective bargaining (Rubio, 2020d, chs.5-7). Postal privatization gained no legislative traction in the 1980s-1990s for its advocates in the Cato Institute and Heritage Foundation. Yet as postal scholar and researcher Steve Hutkins has pointed out, "piecemeal privatization" in the form of work-sharing and outsourcing crept into USPS operations beginning in the mid-1970s with mailers providing presorted letters (Hutkins, 2018).

By the early 2000s, the USPS had become a political football where the USPOD had once been one of the coaches on the sidelines, so to speak. This happened with the discovery that the USPS had overfunded its CSRS payments to the Treasury by as much as $\$ 71$ billion. To reduce, transfer, or return any of those payments back to the USPS would have created an unbalanced unified federal budget (which included USPS revenue and debt). Congress's solution was to impose an annual financial burden on the USPS starting in 2007 for ten years at about $\$ 5.5$ billion a year to prefund a Retiree Health Benefits Fund (RHBF). This is the major cause of the USPS suddenly finding itself in perpetual debt, not the Internet or the Great Recession, although both of those factors have provided major challenges. The USPS plight today also reflects the loss of USPOD political power since it was reorganized into the USPS effective 1971 (Hutkins, 2013). Since then, a kind of "digital determinism" has enabled privatization proponents to explain the USPS debt as proof of its obsolescence in the Cyber Age (Will, 2011). This has combined with what could be called "governance by gaslighting" with relentless conservative excoriation of alleged USPS financial mismanagement. This disingenuous narrative ignores the fact that the USPS typically earned annual operational revenue surpluses between 1995 and 2018 (Hutkins, 2013; Report from the Task Force on the United States Postal System, 2018; Rolando, 2020; Rubio, 2020b, 2020e).

For its part, the USPS has also consistently frustrated sympathetic narratives in how it has enabled competitors and ideological opponents who wanted it to be "leaner and meaner" -meaning pursuing revenue surplus over service and with fewer worker benefits. Those who remember the postal financial crisis of 2009 and media headlines over the next 
three years warning of "default" and "collapse" of the USPS must feel a sense of déjà vu seeing headlines during the COVID-19 pandemic-but with an important change. There is more publicly expressed sympathy today for postal workers and the USPS itself. The former has been the beneficiaries of social media campaigns while the latter enjoyed a 91 percent favorability rating in a national survey by the Pew Research Center (American Postal Workers Union, 2020b). Before DeJoy, the USPS seemed to be strangely surviving an existential battle with privatizing forces while providing crucial services. Advocates of universal postal service, consumer organizations, and postal unions helped push back over the last decade and continue to do so today against arguments for privatization that use the USPS's shortage of cash as evidence of its inability to provide universal service in a financially "sustainable" fashion (Rubio, 2020c; 2020d, ch.8; Sherman, 2020). But with DeJoy's appointment, the rapid deterioration of services suggests a Trojan Horse effect and an existential threat from within the USPS (Jamison, 2020). Once again, we would do well to contrast two Republican administrations fifty years apart: Trump in 2020 trying to take the wheels off the USPS that Nixon imagined as the solution to the government-servicebudget-deficit conundrum.

\section{Nixon, the USPS, and the Last Days of the (Corporate) Liberal Consensus}

At the PRA signing ceremony on August 12, 1970, Nixon praised everyone involved in constructing that compromise bill, including the postal unions that had shot down his idea of calling the USPS a corporation (Nixon, 1970; United States Postal Service Office of Inspector General, 2010). As he did in May 1969, Nixon was praising the nation's postal workers, extolling the law that ensured full collective bargaining rights (except striking) and better pay. Nixon had good reason to praise the postal union leaders present, as the wildcat strike had almost killed his postal reform bill until union negotiations ironically helped bring it back to life. Nixon's post-strike public relations salvage operation was known as the "White House Plan to Sell New Postal Reorganization Legislation." It convened on April 18, 1970-two days after Nixon signed a mammoth pay raise bill for all federal employees that was a direct result of the strike. The April 18 meeting laid out a strategy that included Nixon holding a press conference to tout his bill as one that would "emancipate the postal employee from poor working conditions, poor career opportunities, and poor salaries" (Whitman, 1984).

Now at the PRA signing, Nixon's remarks fairly sang of bipartisanship and capital-labor peace: "This is the American system working in a way that we all like to see it work," he exclaimed, "where we put the country above the party and where we put service to the people above any other interest" (Nixon, 1970). Nixon also made sure to introduce Postmaster General Winton Blount. The former Alabama construction contractor who was about to become the USPS's first Postmaster General (and the last one for the USPOD) had helped get Nixon's bill back on track. Indeed, Blount had insisted before his 1969 appointment that Nixon prioritize postal reform legislation based on the recommendations of the President's Commission on Postal Organization (also known as the "Kappel Commission") in its 1968 final report Toward Postal Excellence. At the PRA signing Nixon left those conclusions unspoken. He had said it all before, so there was no need to rub it in (Nixon, 1970; Rubio, 2020d, chs.2, 5-6). But it is worth remembering here that the report's summary begins by emphasizing that the way out of the Post Office's "crisis" of operating each year "at a huge 
financial loss" is to create a "self-supporting" government-owned "postal corporation." That corporation would then resolve the contradiction between the Post Office's inconsistent status as "one of the nation's largest businesses" that they argued was "not run as a business (President's Commission on Postal Organization, quotes from 1-2)." For its part, the PRA left subsequent generations to invent shorthand terminology ("hybrid," "agency/ corporation," "quasi-government corporation," "quasi-corporate government agency," etc....) with its own insistently neutral official description of the USPS as "an independent establishment of the executive branch" (Postal Reorganization Act, 1970, 201). If anything, the USPS today has stretched that contradiction to its limits because it not only is fundamentally a public service; it is also a commercial and political institution.

Ominously, in 1968, the Kappel Commission report interjected how privatization was not an option at that time "largely for reasons of financing," while allowing for privatization in the future "if such a transfer were considered feasible and in the public interest" (President's Commission on Postal Organization, quotes on 1-2). The implication seems to be here that if the future USPS proved to be somehow not "corporate enough," it would then need to become all-corporate. If it appeared that Nixon in August 1970 was stealing from the Democratic Party playbook, it was because there was still that much left of the "liberal consensus" then (Chafe, 2015, 97-98), although in the end, liberal Democratic postal legislation supported by the unions that would have reformed the USPOD without corporatizing it lost out to Nixon's bill. Under the bipartisan compromise approved by Nixon, postal services would expand, sound business principles and semi-autonomy would improve service and work culture, and postal workers' would enjoy stronger union representation (privatesector style) for this sole group of federal government employees to enjoy full collective bargaining rights. This would also ensure labor peace and high productivity. In fact, Nixon was "stealing from Democrats' playbook," as the Kappel Commission had been convened by President Lyndon Johnson at the behest of his Postmaster General Lawrence O'Brien (President's Commission on Postal Organization, quotes from 1-2). This was two years before Watergate and the 1972 election, when Nixon campaign operatives were arrested for breaking into the Democratic Party headquarters - so one could say that Nixon literally was stealing Democrats' playbook as the operatives' plan had been to steal Democratic campaign strategy documents (Chafe, 2015, 402-409).

The shared political assumptions of the 1970s were quite different from today. One might even say that we have lived in a different time for some time. On the other hand, the same issues of universal service, business models, congressional oversight, government agency autonomy, and labor-management relations endure. The USPS will never be divorced from politics, and its financial health is a barometer of how effectively our democracy functions by ensuring that the nation's mail network helps connect Americans with their elected officials and each other. Only outright repeal of Title 39 can eliminate or privatize the USPS, but lack of political will, can still cripple it into something barely recognizable from any of its previous statutory mandates. Looking ahead from this writing in mid-October 2020, there may indeed be a USPS insolvency crisis in March or October 2021 as has been suggested, or even at some future date. But the dynamic has also changed since June 15. First, as noted before, Trump now has a pliant postmaster general with whom he has a close political relationship (Heckman, 2020; Piette, 2020). Second, there are now only Trump appointees on the USPS BOG. The last non-Trump appointed governors besides Postmaster General Brennan were also the last ones with postal experience. David C. Williams, USPS OIG and BOG vice-chair, resigned in protest of Trump's interference in USPS matters in April. Deputy Postmaster General Ronald Stroman, an expert in voting by mail, was reportedly forced out in May. Megan Brennan, who retired 
in June, had resisted Trump's calls to raise parcel rates (Hart, 2020; Rubio, 2020c). On the other hand, as polls in 2020 have continued to show popular sympathy for the USPS while Trump's popularity simultaneously keeps slipping, a Democratic administration taking office in January would likely provide some relief for the USPS (Goodkind, 2020). However, this chronic crisis will not end until Congress alleviates the debt burden it imposed on the USPS in 2006, and crafts legislation that allows the USPS to move the U.S. mail without compulsion of profit or denial of labor rights to its employees.

\section{Conclusion: Trump, the USPS, and the Death of the Neoliberal Consensus}

For nearly two centuries, postal workers had two employers: the post office and Congress, and for a nearly a century they had national unions that mostly functioned as lobbyists. The 1970 strike was a culmination of postal worker collective anger and ultimately rejection of this status quo. It also coincided and clashed with some shared assumptions on Capitol Hill that postal reform must be based on a corporate structure. While the strikers succeeded in forcing Nixon to the bargaining table and winning a compromise that was not entirely his postal corporation model, it nevertheless produced a hybrid that made put postal workers in a special category of federal employees. In 2010, the USPS OIG blogged a brief history of the postal strike, and observed that the binding arbitration clause of Title 39 "meant that the Postal Service has never been able to exert control over its labor costs" (United States Postal Service Office of the Inspector General, 2010). Postal workers still lack the right to strike, in contrast with auto or steel workers who can use that weapon at their own risk and discretion. Those private sector industries can either pressure their unions to agree to contract terms or find ways to cut costs or increase production to maintain profits. The USPS, however, is in that liminal space between government agency and private corporation. Besides being obligated to negotiate and respect its unions, it must also be self-financing, and is subject to oversight by Congress and the Postal Regulatory Commission (PRC) that also limits its ability to compete, although the USPS still enjoys a first-class mail monopoly under the private express statutes (United States Postal Service, 2020b, 11).

The USPS in 2020 certainly seems stuck in a seemingly permanent service/business conundrum. Reform is clearly needed for the USPS, although I think historian Daniel Carpenter overshot the mark in describing the USPS as a neoliberal creation. Economist Milton Friedman, a founder of neoliberal theory, opposed the USPOD's "monopoly" and supported postal privatization (Carpenter, 2020; Friedman, 2002, 29-20). What we think of as the neoliberal capitalist ideology that espouses free market, free trade, privatization, social spending cuts, balanced budgets, and contingent labor (all of these also typically associated with conservatism) does not lend itself to the expansionism of the USPS, particularly with regard to labor rights. Neoliberalism became a bipartisan consensus by the 1990s during the administration of President Bill Clinton, notwithstanding the conservative Republican "Gingrich Revolution" of the 1990s (Chafe, 2015, ch.17; Fletcher \& Gapasin, 2008). Arguably, this "neoliberal consensus" persisted into the 2010s as Democrats watched opportunities slip away to repeal the PAEA. Was this because they lost majorities in the House in 2011 and the Senate in 2014, or accepted the conservative narrative of businesslike postal service, or both? Was the PRA as dead to them as it apparently was to Republicans (Rubio, 2020d, ch.8)? It is worth quoting the first subsection of the 1970 PRA here, as a reminder of what that law's bipartisan authors declared it would do: 
The United States Postal Service shall be operated as a basic and fundamental service provided to the people by the Government of the United States, authorized by the Constitution, created by Act of Congress, and supported by the people. The Postal Service shall have as its basic function the obligation to provide postal services to bind the Nation together through the personal, educational, literary, and business correspondence of the people. It shall provide prompt, reliable, and efficient services to patrons in all areas and shall render postal services to all communities. The costs of establishing and maintaining the Postal Service shall not be apportioned to impair the overall value of such service to the people (Postal Reorganization Act, 101 (a), Postal Policy).

Nixon's faith that the USPS hybrid would work out due to a combination of business world "know-how," a government imprimatur that would protect it from politics, and a future of ever-increasing mail volume-all aided by higher productivity and automation to lower labor costs-actually lasted almost four decades before it ran into trouble. It took a politically manufactured (but very real) financial crisis in 2009 to break something that all evidence shows was never broken in the first place, and an economic and health crisis in 2020 to push it even further to the brink. The policies of the previous three postmasters general (all USPS career employees) represented to varying degrees a rearguard action in trying to stave off insolvency under the crushing RHBF debt. There were unsuccessful attempts at curtailing services, such as ending Saturday delivery, or curbing worker benefits. But they were able to implement others, such as closing post offices and mailsorting facilities, cutting hours, selling postal buildings, and relaxing service standards for first-class mail starting in 2012. The savings or proposed savings were always minimal, but the policies reflected the same neoliberal assumptions that kept Congress from rescuing the USPS from the legislated and therefore manufactured PAEA debt burden (Brown, 2012; Rein, 2015; Rubio, 2020d, ch.8). Put simply, the USPS, its employees, and postal consumers were supposed to learn to live with austerity in service and labor rights within a "reformed" mail corporation.

The USPS is an essential infrastructure institution that currently employs 633,108 government workers to move the mail (USPS, 2020). If it were solely a business, this would not be a political issue. Instead there would likely be frantic shareholder meetings and pleas for a "too big to fail" bailout from Congress. If on the other hand the USPS was solely a government agency as it was before the PRA, we would not even be discussing its possible imminent insolvency-with many Americans worrying that, in the 1966 lyrics of singer/songwriter Bob Dylan, "the post office has been stolen, and the mailbox is locked" (Dylan, 1966). Nor would we have a president able to suggest that he could issue executive orders to stop mail-in balloting based on his publicly displayed fear that most of those votes would go to his political opponent. Nor would President Trump be able to proclaim that he would refuse to sign legislation providing the USPS funds to operate in order to keep it from being able to handle those ballots (Gardner et al., 2020). We would also not have a postmaster general enabling Trump's attempted voter suppression with policies cited above (Washington v. Trump, 2020, 2).

Besides slowing the mail down by banning employee overtime plus extra and late truck trips from mail processing centers, USPS under DeJoy in July began removing mail collection boxes around the country in both urban and rural areas, cutting postal retail hours (Meet the New Boss, 2020). DeJoy also ordered the dismantling of 671 mail-sorting machines by August 1. Through his counsel Thomas Marshall, he warned 46 states and the District of Columbia that the USPS could not ensure that all ballots in the mail would be 
delivered to election boards on time during the November general election, reneging on past policies of treating all mail-in ballots as first-class (most are marketing mail). The brazenness of all of DeJoy's chaotic and counter-productive policies even provoked a senior official in the nonpartisan League of Women Voters to denounce them as "voter suppression" (Bogage, 2020a; Cox et al., 2020; Kumar, 2020; Murphy, 2020). Steve Hutkins made this point after uncovering internal documents revealing DeJoy's goal of reducing workhours: "Cutting 64 million work hours would save about $\$ 3$ billion in labor costs. That equates to about 33,000 jobs. It may be the largest cost-cutting operation ever attempted by the Postal Service" (Hutkins, 2020b). This amounts to pushing these frontline workers past the point of exhaustion, with 10,000 having tested positive for the coronavirus and 52,000 having used sick leave for illness or quarantine (as of mid-September), insufficient staffing, cutbacks in overtime, and speed-up (Hutkins, 2020c).

The defense of a "more efficient business model" is curious here, although neoliberal ideology still provides cover for a gradual privatization by dismissing universal postal service. Even if the USPS were a business, that business would still be its service-the quick moving of time-sensitive mail. In addition, the investigation begun in September 2020 by the House Oversight and Reform Committee of DeJoy's possible campaign law violations reminds us that corporate corruption at the expense of both stockholders and consumers becomes considerably magnified when combined with government service (Davis et al., 2020). Political corruption in government service, even if ignored by the USPS Board of Governors, is still accountable to the judicial system. While the House Oversight committee seemed helpless to block DeJoy's mail curtailment policies, a federal district court judge in Washington state on September 17, 2020, issued a temporary injunction that did just that. Judge Stanley A. Bastian issued the first of what have become seven separate national injunctions (as of October 10) by four different federal district court judges around the country to stop mail delays, especially mail-in ballots. (An eighth case brought by the governor of Montana-out of twelve total lawsuits nationwide-was settled on October 14 in Bullock v. USPS that mandated a reversal of DeJoy's mail delay policies.) Judge Bastian observed that the USPS changes reflected the Trump administration's "intentional effort...to disrupt and challenge the legitimacy of upcoming local, state, and federal elections" (Hutkins, 2020c; Ingraham \& Guskin, 2020; Viebeck \& Bogage, 2020; Washington v. Trump, 2020, 2). In addition, lest we imagine that only lawyers and judges can save the post office, postal workers have been engaged in quiet acts of resistance during the DeJoy delays (Bogage, 2020d), as well as noisy advocacy with labor-consumer coalitions like Stand By Your Mail (Stand By Your Mail, 2020).

As partisan a political actor as Nixon could be in his day (Cowie, 2010), the PRA that he signed into law was intended to take politics out of the post office, not convert it into a partisan instrument (Nixon, 1970). But the USPS was unintentionally created as a conundrum of service and business. While successful for a few decades, it was in fact a ticking time bomb. If anyone did anticipate that someday there would emerge forces using the USPS's new design to run it into the ground, they failed in warning the public. The USPS's hybrid format provided a measure of autonomy and freed it from political control. On the other hand, congressional oversight remained, but without the annual congressional subsidies to move the nation's mail.

Now, in the autumn of a tumultuous year, the USPS - for the first time in its 245-year history-has become a partisan political weapon for reelection in the hands of an authoritarian president already committed to that agency's privatization. Yet a poll taken in late August 2020 found Americans by more than a two to one margin preferring that the Postal Service operate as a service rather than as a business (Ingraham \& Guskin, 2020). 
Ironically and unintentionally, DeJoy's and Trump's policies have provided a practical demonstration of the perils of postal privatization, partisan manipulation, and insolvency of a basic government service. Whether this society can muster the political will to prevent that kind of tragedy remains to be seen.

In fact, with 22.2 million Americans already having voted in record numbers by mail or in-person by October 16, 2020, there appears to be an insurgency that includes a desire to preserve the postal service as America's post office (Riccardi \& Kastanis, 2020). Democrats who captured the House and its committees after the 2018 midterm elections were able to introduce the USPS Fairness Act on April 29, 2019, and passed on February 5, 2020, that would repeal the PAEA's prefunding requirement, forgiving its outstanding RHBF debt (H.R. 2382 (2019-2020). The House followed up on May 15, 2020, with H.R. 6800, a huge stimulus package that included emergency funds for the USPS due to the coronavirus pandemic, hazard pay for "postal and other essential frontline workers," and funds to enable mail-in voting (American Postal Workers Union, 2020a). Both bills sit in the Senate awaiting action, but House advocacy of the protection of universal postal service and labor is finally a matter of twenty-first century record. Articulating similar sentiments is the popular website Save the Post Office.com, which recently proposed a unique thirteen-point postal reform agenda. Their plan aims to fix the conundrum that the PRA authors thought they were resolving in 1970 while unintentionally creating a new one (Hutkins, 2020a). As a historian, I make no predictions about its chances. But I have hope for initiatives like this and look forward to writing their story after they happen.

\section{Declarations}

Ethical Approval This article does not contain any studies with human participants or animals performed by either of the authors.

Informed Consent There were no individual participants in this study and, thus, informed consent does not apply to this study.

Conflict of Interest The authors declare that they have no conflicts of interest.

\section{References}

Acemoglu, D., Moscona, J., \& Robinson, J. A. (2016). State capacity and American technology: Evidence from the nineteenth century. American Economic Review, 106(5), 61-67. https://www.aeaweb.org/artic les?id=10.1257/aer.p20161071. Accessed 1 July 2019.

American Postal Workers Union. (2020a). House passes new stimulus bill-postal funding included. https:// www.apwu.org/news/house-passes-new-stimulus-bill-postal-funding-included. Accessed 16 May 2020.

American Postal Workers Union. (2020b). Public shows strong support for postal service. https://www. apwu.org/news/public-shows-strong-support-postal-service. Accessed 20 May 2020

Baxter, V. K. (1994). Labor and politics in the U.S. postal service. Plenum.

Bogage, J. (2020a). Here's why the Postal Service wanted to remove hundreds of mail-sorting machines. Washington Post. https://www.washingtonpost.com/business/2020/08/20/postal-service-mail-sortersremovals/. Accessed 20 Aug 2020.

Bogage, J. (2020b). Postal Service memos detail 'difficult' changes, including slower mail delivery. Washington Post. https://www.washingtonpost.com/business/2020/07/14/postal-service-trump-dejoy-delaymail/. Accessed 14 July 2020. 
Bogage, J. (2020c). Postal Service overhauls leadership as Democrats press for investigation of mail delays. Washington Post. https://www.washingtonpost.com/business/2020/08/07/postal-serviceinvestigation-dejoy/. Accessed 7 Aug 2020.

Bogage, J. (2020d). Postal Service workers quietly resist DeJoy's changes with eye on election. Washington Post. https://www.washingtonpost.com/business/2020/09/29/usps-workers-election-mail/. Accessed 29 Sept 2020.

Bogage, J. (2020e). Treasury agrees to lend Postal Service $\$ 10$ billion in trade for rivals' shipping contracts. Washington Post. https://www.washingtonpost.com/business/2020/07/29/postal-service-treas ury-loan/. Accessed 29 July 2020.

Bogage, J. (2020f). Top Democrats say postmaster general acknowledged new policies that workers say are delaying mail. Washington Post. https://www.washingtonpost.com/politics/2020/08/06/ top-democrats-say-postmaster-general-acknowledged-new-policies-that-workers-say-are-delayingmail/. Accessed 6 Aug 2020.

Bogage, J. (2020g). Under siege from Trump, U.S. Postal Service finds surprising financial upside in pandemic. Washington Post. https://www.washingtonpost.com/business/2020/06/25/postal-servicepackages-coronavirus/. Accessed 25 June 2020.

Broadwater, L., Fuchs, H., \& Corasaniti, N. (2020). The Postal Service warns states it may not meet mail-in ballot deadlines. New York Times. https://www.nytimes.com/2020/08/15/us/elections/thepostal-service-warns-states-it-may-not-meet-mail-in-ballot-deadlines.html. Accessed 15 Aug 2020.

Brown, K. C. (2012). Congress ties Postal Service into knots. Remapping Debate. http://www.remap pingdebate.org/article/congress-ties-postal-service-knots. Accessed 1 Nov 2012.

Carpenter, D. (2020). American Democracy is in the mail. Boston Review. http://bostonreview.net/polit ics-law-justice/daniel-carpenter-american-democracy-mail. Accessed 10 Sept 2020.

Chafe, W. H. (2015). The unfinished journey: America since world war II. Oxford University Press.

Cowie, J. (2010). Stayin' alive: The 1970s and the last days of the working class. The New Press.

Cox, E., Viebeck, E., Bogage, J., \& Ingraham, C. (2020). Postal Service warns 46 states their voters could be disenfranchised by delayed mail-in ballots. Washington Post. https://www.washingtonpost. com/local/md-politics/usps-states-delayed-mail-in-ballots/2020/08/14/64bf3c3c-dcc7-11ea-8051d5f887d73381_story.html. Accessed 14 Aug 2020

Davis, A. C., Gardner, A., \& Swaine, J. (2020). Louis DeJoy's rise as GOP fundraiser was powered by contributions from company workers who were later reimbursed, former employees say. Washington Post. https://www.washingtonpost.com/investigations/louis-dejoy-campaign-contributions/ 2020/09/06/1187bc2c-e3fe-11ea-8181-606e603bb1c4_story.html. Accessed 6 Sept 2020.

DeJoy, L. (2020). Postmaster general statement on operational excellence and financial stability. Postalnews.com. http://postalnews.com/blog/2020/07/28/postmaster-general-statement-on-operational-excel lence-and-financial-stability/?utm_campaign=shareaholic\&utm_medium=email_this\&utm_source= email. Accessed 28 July 2020.

DeJoy, L., \& Cronkhite, I. (2020). USPS memorandum on restructuring. United States Postal Service.

Dylan, B. (1966). Stuck inside of mobile with the Memphis blues again. Blonde on Blonde LP

Edmondson, C., Fandos, N., Rappeport, A., Broadwater, L., \& Cochrane, E. (2020). Key highlights of Louis DeJoy's testimony to a house panel. New York Times. https://www.nytimes.com/2020/08/24/ us/politics/postal-service-dejoy-testimony.html. Accessed 24 Aug 2020.

Fletcher, B., Jr., \& Gapasin, F. (2008). Solidarity divided: The crisis in organized labor and a new path toward social justice. University of California Press.

Friedman, M. (2002). Capitalism and freedom, 40th annived. University of Chicago Press.

Gardner, A., Dawsey, J., \& Kane, P. (2020). Trump opposes election aid for states and Postal Service bailout, threatening Nov. 3 vote. Washington Post. https:/www.washingtonpost.com/politics/ trump-mail-voting/2020/08/13/3eb9ac62-dd70-11ea-809e-b8be57ba616e_story.html?hpid=hp_hptop-table-main_trump-vote-1115am\%3Ahomepage\%2Fstory-ans. Accessed 13 Aug 2020.

Germano, T. G. (1983). Labor Relations in the United States Postal Service. City University of New York Graduate Center Ph.D. diss.

Goodkind, N. (2020). The fate of the USPS may be on the ballot in November. Fortune. https://fortune. com/2020/04/27/usps-bailout-biden-trump/. Accessed 27 Apr 2020.

Graves, L. (2020). The billionaire behind efforts to kill the U.S. Postal Service. In the Public Interest.org. https:// www.inthepublicinterest.org/wp-content/uploads/ITPI_USPSPrivatization_July2020.pdf. Accessed 2 Aug 2020.

H.R. 2382 (2019-2020). 116th Congress. (USPS Fairness Act). https://www.congress.gov/bill/116thcongress/house-bill/2382\#: :text=Passed $\% 20$ House $\% 20(02 \% 2 F 05 \% 2 F 2020) \&$ text=This $\% 20$ bill\% 20repeals\%20the \%20requirement,prepay\%20future\%20retirement\%20health\%20benefits 2020)\& 
text=This $\% 20$ bill $\% 20$ repeals $\% 20$ the $\% 20$ requirement,prepay $\% 20$ future $\% 20$ retirement $\% 20$ health $\%$ 20benefits. Accessed 30 Mar 2020.

Halpern, M. (2003). Unions, radicals, and democratic presidents: Seeking social change in the twentieth century. Praeger.

Hart, R. P. (2020). Trump and us: What he says and why people listen. Cambridge: Cambridge University Press.

Heckman, J. (2020). New postmaster general outlines USPS 'trajectory for success' amid financial challenges. Federal News Network.

Hutkins, S. (2018). How to privatize the post office: Piece by piece, step by step. https://savethepostoffice. com/how-to-privatize-the-postoffice-piece-by-piece-step-by-step/. Accessed 31 July 2018.

Hutkins, S. (2020a). A new agenda for postal reform. Save the Post Office.com. https://www.savethepostoffi ce.com/a-new-agenda-for-postal-reform/. Accessed 18 Oct 2018.

Hutkins, S. (2020b). Do it now: A timeline of the postal service's work hour reduction plan. Save the Post Office.com. https://www.savethepostoffice.com/do-it-now-a-timeline-of-the-postal-services-work-hourreduction-plan/. Accessed 1 Oct 2018.

Hutkins, S. (2020c). Lawsuits against DeJoy, USPS \& Trump over mail delays and election mail. Save the Post Office.com. https://www.savethepostoffice.com/lawsuits-against-dejoy-usps-trump/. Accessed 18 Oct 2018.

Hutkins, S. (2013). How the postal service began prefunding retiree health care and fell into a deep hole. http://www.savethepostoffice.com/how-postal-service-began-prefunding-retiree-health-care-and-felldeep-hole. Accessed 2 Jan 2013.

Ingraham, C., \& Guskin, E. (2020). Poll: USPS should be run like a public service, not a business, Americans say 2-to-1. Washington Post. https://www.washingtonpost.com/business/2020/09/28/usps-pollvote-by-mail-public-service-business/. Accessed 28 Sept 2020.

Jamison, M. (2020). DeJoy's fix for the post office: The wrong time, the wrong plan, the wrong man. Save the Post Office.com. https://www.savethepostoffice.com/dejoys-fix-for-the-post-office-the-wrong-timethe-wrong-plan-the-wrong-man/. Accessed 9 Aug 2020.

John, R. (2020). The Founders never intended the U.S. Postal Service to be managed like a business. Washington Post. https://www.washingtonpost.com/outlook/2020/04/27/founders-never-intended-postalservice-be-managed-like-business/?tid=ss_mail. Accessed 27 Apr 2020.

Johnson, M. (2020). Postmaster General warns that Postal Service will run out of money by end of fiscal year without aid. The Hill. https://thehill.com/homenews/house/492067-postmaster-general-warnsthat-postal-service-will-run-out-of-money-by-end-of. Accessed 9 Apr 2020.

Kosar, K. R. (2009). The postal accountability and enhancement act: Overview and issues for congress. Congressional Research Service. https://www.fas.org/sgp/crs/misc/R40983.pdf. Accessed 14 Dec 2009.

Kumar, A. (2020). Trump aides exploring executive actions to curb voting by mail. Politico.com. https:// www.politico.com/news/2020/08/08/trump-wants-to-cut-mail-in-voting-the-republican-machine-ishelping-him-3924282020/08/08/trump-wants-to-cut-mail-in-voting-the-republican-machine-is-helpi ng-him-392428. Accessed 8 Aug 2020.

Lee, M. Y. H., \& Bogage, J. (2020). Postal Service backlog sparks worries that ballot delivery could be delayed in November. Washington Post. https://www.washingtonpost.com/politics/postal-service-backl og-sparks-worries-that-ballot-delivery-could-be-delayed-in-november/2020/07/30/cb19f1f4-d1d011ea-8d32-1ebf4e9d8e0d_story.html. Accessed 30 July 2020.

"Meet the New Boss...Better than the Old Boss?" (2020). Postal Times. https://www.postaltimes.com/posta lnews/meet-the-new-boss-better-than-the-old-boss/. Accessed 11 July 2020.

Mikusko, M. B., \& Miller, F. J. (2014). Carriers in a common cause: A history of letter carriers and the $N A L C$, 125th anniversary ed. National Association of Letter Carriers.

Murphy, P. P. (2020). USPS removes mail collection boxes and reduces post office hours as critics accuse Trump administration of voter suppression. CNN.com. https://a.msn.com/r/2/BB17YOoJ?m=en-us\& referrerID=InAppShare. Accessed 14 Aug 2020.

National Association of Letter Carriers. (2020a). NALC files national-level grievance regarding USPS delivery initiative. NALC News and Information. https://www.nalc.org/news/nalc-updates/nalc-filesnational-level-grievance-regarding-usps-delivery-initiative\#: :text=NALC $\% 20$ files $\% 20$ national $\%$ 2Dlevel\%20grievance\%20regarding\%20USPS\%20delivery\%20initiative,-Earlier\%20this\%20week\& text=F\%20of\%20the \%20National\%20Agreement,\%2FAfternoon\%20Sortation\%20(ESAS). Accessed 7 Aug 2020.

National Association of Letter Carriers. (2020b). National-Level Grievance over Expedited Street/Afternoon Sortation (ESAS) Settled. https://www.nalc.org/news/nalc-updates/national-level-grievance-overexpedited-streetafternoon-sortation-esas-settled. Accessed 1 Sept 2020. 
National Association of Letter Carriers. (2020c). Statement from NALC on Service Issues. NALC News and Information. https:/www.nalc.org/news/nalc-updates/statement-from-nalc-on-serviceissues. Accessed 3 Aug 2020.

National Association of Letter Carriers. (2020d). USPS announces new ESAS delivery initiative test. NALC News and Information, https://www.nalc.org/news/nalc-updates/usps-announces-new-esas-deliveryinitiative-test. Accessed 21 July 2020.

National Association of Letter Carriers. (2020e). USPS to initiate office activities study. NALC News and Information. https://www.nalc.org/news/nalc-updates/usps-to-initiate-office-activities-study\#: :text=During\% 20a\%20meeting\%20held\%20on,data\%20related\%20to\%20office\%20activities. Accessed 1 Aug 2020.

Nelson, D. A. (1969). Draft of President's postal reform message to Congress Box 39, folder 1, Ehrlichman Collection, Richard M. Nixon Presidential Library and Museum, Yorba Linda, California.

Nixon, R. M. (1969). Nixon Special Message to the Congress on Postal Reform. University of Michigan Digital Library. The Public Papers of the Presidents of The United States. p. 409. https://quod.lib. umich.edu/p/ppotpus/4731731.1969.001?rgn=main;view=fulltext1969.001?rgn=main; view=fullt ext. Accessed 27 Mar 2015.

Nixon, R. M. (1970). Remarks on signing the postal reorganization act. The American Presidency Project. https://www.presidency.ucsb.edu/documents/remarks-signing-the-postal-reorganization-act. Accessed 17 Mar 2015.

Piette, J. (2020). New postmaster general is an expert job-killer. Labor Notes. https://labornotes.org/ blogs/2020/05/new-postmaster-generalexpert-job-killer.

Politi, D. (2020). Democrats decry "sabotage" after "Friday night massacre" at Postal Service. Salon. com. https://slate.com/news-and-politics/2020/08/democrats-sabotage-usps-friday-night-massacrepostal-service.html. Accessed 8 Aug 2020.

Postal Reorganization Act, U.S. Code 39 (1970), 101 et seq.

President's Commission on Postal Organization. (1968). Toward postal excellence: Report of the President's Commission on Postal Organization. https://ufdc.ufl.edu/AA00024775/00001. Accessed 29 May 2019.

President's Commission on the United States Postal Service. (2003). Embracing the future: Making the tough choices to preserve Universal Mail Service. https://www.treasury.gov/press-center/press-relea ses/documents/pcusps_report.pdf. Accessed 29 May 2019

Rein, L. (2015). It's not just you: Letters really are taking longer to get delivered. Washington Post. https://www.washingtonpost.com/news/federal-eye/wp/2015/04/27/as-usps-slows-down-mail-deliv ery-some-letters-are-taking-even-longer-to-arrive-than-the-new-rules-allow/. Accessed 27 Apr 2015.

Rein, L., \& Bogage, J. (2020). Trump says he will block coronavirus aid for U.S. Postal Service if it doesn't hike prices immediately. Washington Post. https://www.washingtonpost.com/us-policy/ 2020/04/24/trump-postal-service-loan-treasury/. Accessed 24 Apr 2020.

Report from the Task Force on the United States Postal System. (2018). United States Postal Service: A sustainable path forward.

“"Return to sender': Postal Service problems affecting voters.” (2020). San Antonio Times. https:// www.mysanantonio.com/news/article/Return-to-sender-Postal-Service-problems-15473133. php. Accessed 12 Aug 2020.

Riccardi, N., \& Kastanis, A. (2020). Record avalanche of early votes transforms the 2020 election. AP News, https://apnews.com/article/record-early-votes-2020-transforms-efd6eefbd3d140bdc8909360de0bff62.

Rolando, F. (2020). President Trump is Being Misinformed about the Postal Service. NALC.org. https://nalc.org/news/nalc-updates/president-trump-is-being-misinformed-about-the-postal-servi ce. Accessed 25 Apr 2020.

Rubio, P. F. (2010). There's always work at the post office: African American postal workers and the fight for jobs, justice, and equality. University of North Carolina Press.

Rubio, P. F. (2020a). I carried the mail. Postmaster General DeJoy should be returned to sender. Charlotte Observer. https://www.charlotteobserver.com/opinion/article245442450.html. Accessed 3 Sept 2020.

Rubio, P. F. (2020b). Public service versus business: Delivering on the promise of the United States Postal Service. AHA Perspectives on History. https://www.historians.org/publications-and-direc tories/perspectives-on-history/summer-2020/public-service-versus-business-delivering-on-thepromise-of-the-united-states-postal-service. Accessed 1 July 2020.

Rubio, P. F. (2020c). Save the Postal Service. The Atlantic.com. https://www.theatlantic.com/ideas/archi ve/2020/04/why-postal-service-worth-saving/610672/. Accessed 24 Apr 2020.

Rubio, P. F. (2020d). Undelivered: From the great postal strike of 1970 to the manufactured crisis of the U.S. postal service. University of North Carolina Press. 
Rubio, P. F. (2020e). You've got no mail. The Baffler.com. https://thebaffler.com/latest/youve-got-nomail-rubio. Accessed 6 Aug 2020.

Rushing, E. (2020). Mail delays are frustrating Philly residents, and a short-staffed Postal Service is struggling to keep up. Philadelphia Inquirer. http://inquirer.com/news/philadelphia/usps-trackingin-transit-late-mail-delivery-philadelphia-packages-postal-service-20200802.html. Accessed 2 Aug 2020 .

Sherman, E. (2020). Inside the Radical Republican war on the Post Office. DC Report. https://www. dcreport.org/2020/06/01/inside-the-radical-republican-war-on-the-post-office/. Accessed 2 June 2020 .

Slisco, A. (2020). Mail-in voting concerns prompt house to ask postmaster general to hearing. Newsweek. https://www.newsweek.com/mail-voting-concerns-prompt-house-ask-postmaster-generalhearing-1522528. Accessed 3 Aug 2020.

Stand By Your Mail. (2020). https://www.standbyyourmail.org/. Accessed 15 Oct 2020.

United States Postal Service. (2020a). Postmaster General Louis DeJoy's opening remarks for the USPS Board of Governors Aug. 7 Meeting. https://about.usps.com/who/leadership/board-governors/brief ings/welcome.htm. Accessed 7 Aug 2020.

United States Postal Service. (2020b). The United States Postal Service: An American History, 17752020. https://about.usps.com/publications/pub100.pdf. Accessed 20 Aug 2020.

United States Postal Service. (2002). 2002 Transformation Plan. https://about.usps.com/strategic-planning/ transform.htm. Accessed 16 July 2018.

United States Postal Service Office of the Inspector General. (2010). The Postal Strike of 1970. https:// www.uspsoig.gov/blog/postal-strike-1970. Accessed 18 March 2020.

USPS Postal Facts. (2020). https://facts.usps.com/size-and-scope/. Accessed 1 July 2020.

"USPS Reaches Agreement with Treasury on \$10 Billion CARES Act Lending Authority." (2020). Postalnews.com. http://postalnews.com/blog/2020/07/29/usps-reaches-agreement-with-treasury-on-10-billi on-cares-act-lending-authority/. Accessed 29 July 2020.

Viebeck, E., \& Bogage, J. (2020). Federal judge temporarily blocks USPS operational changes amid concerns about mail slowdowns, election. Washington Post. https:/www.washingtonpost.com/politics/ federal-judge-issues-temporary-injunction-against-usps-operational-changes-amid-concerns-aboutmail-slowdowns/2020/09/17/34fb85a0-f91e-11ea-a275-1a2c2d36e1f1_story.html?hpid=hp_no-name_ 430p-0917-uspssuit\%3Ahomepage\%2Fstory-ans. Accessed 17 Sept 2020.

Waldman, P. (2020). How Trump's war on the Postal Service could create an election nightmare. Washington Post. https:/www.washingtonpost.com/opinions/2020/07/15/how-trumps-war-postal-servicecould-create-an-election-nightmare/. Accessed 15 July 2020.

Washington v. Trump. (2020). Order granting plaintiffs' motion for preliminary injunction. Stanley A. Bastian, Chief United States District Judge. United States District Court Eastern District of Washington.

Whitman, D. (1984). White House Plan to Sell New Postal Reorganization Legislation, April 18, 1970. Appendix C, Kennedy School of Government, Center for Press, Politics and Public Policy, Harvard University, in USPS Files of the Historian, Washington, D.C.

Will, G. (2011). Privatize the nation's mail delivery. Washington Post. https://www.washingtonpost.com/ opinions/privatize-the-nations-mail-delivery/2011/11/23/gIQAe2J7wN_story.html. Accessed 25 Nov 2011.

Publisher's Note Springer Nature remains neutral with regard to jurisdictional claims in published maps and institutional affiliations. 